Portland State University

PDXScholar

$5-17-2018$

\title{
Erasing History? Contextualizing Modern Monument Destruction through an Archaeological Lens
}

Stephanie Holton

Portland State University

Follow this and additional works at: https://pdxscholar.library.pdx.edu/honorstheses

Let us know how access to this document benefits you.

Recommended Citation

Holton, Stephanie, "Erasing History? Contextualizing Modern Monument Destruction through an Archaeological Lens" (2018). University Honors Theses. Paper 528.

https://doi.org/10.15760/honors.533

This Thesis is brought to you for free and open access. It has been accepted for inclusion in University Honors Theses by an authorized administrator of PDXScholar. Please contact us if we can make this document more accessible: pdxscholar@pdx.edu. 
Erasing History? Contextualizing Modern Monument Destruction through an Archaeological Lens

by

\section{Steph Holton}

An undergraduate honors thesis submitted in partial fulfillment of the

requirements for the degree of

Bachelor of Arts

in

University Honors

and

Anthropology

Thesis Adviser

Virginia Butler

Portland State University 


\begin{abstract}
Cultures throughout the world have expended great amounts of energy in the practice of monument construction. Often, the resulting monuments become a part of the archaeological record through processes of either environmental or cultural deposition, and sometimes even by means of intentional destruction. The destruction of such an energetically costly object begs explanation, and is particularly relevant given the movement currently taking place across the United States to destroy or relocate standing Confederate monuments. My project sought to place the current monument destruction in a larger historical context through the analysis of three archaeological case studies. I attempted to separate intentional destruction vs. natural site formation processes, and drew on independent archival records to assess the relationship between monuments and written history. Monuments represent a constructed narrative of the past and inevitably outlive their intended function in society, which has ultimately been the cause of their destruction throughout human history.
\end{abstract}




\section{INTRODUCTION}

The American Civil War ended in 1865, and as a result, so too did the Confederate States

of America. However, the decades following Reconstruction in the American South saw a boom in Confederate monument construction and today, over a century and a half later, over 700 Confederate statues as far Northwest as Seattle, WA and as far Southeast as Orlando, FL stand scattered across the United States. Individually, many of these statues are under considerations for destruction or relocation, and collectively, the function and political correctness of these remaining Confederate monuments have become a divisive conversation for the American public (Bidgood 2017; Brundage \& Joseph 2017; Levinson 1998; Suerth 2017; The Southern Poverty Law Center 2016).

Mankind has erected monuments for symbolic purposes for at least 11,000 years (Greaves and Helwing 2003). The archaeological record contains examples from across the globe and throughout human history of figures created, displayed, forgotten, and often deliberately destroyed. This millennia long recurrence begs certain questions about monuments' function and lifespan, and the insights derived from pursuing these questions may shed light on the situation concerning Confederate monuments across the country. In this paper I provide an interdisciplinary explanation of the meaning of monuments in public spheres, considering research in history, architecture, geography, and anthropology. Then I go on to examine three case studies of intentional destruction of monuments in the archaeological record-Olmec monuments, constructed by Mesoamerican peoples c. 1200-400 B.C.; the mortuary temple of Hatshepsut, fifth pharaoh of the Eighteenth Dynasty of Egypt, reigning c. 1479-1458 B.C.; and the Grand Buddhas of Bamiyan, constructed between 600-800 B.C. I undertake this work to establish an understanding of the circumstances surrounding destruction events of large-scale 
archaeological features in the past and to situate modern monument destruction in the United States within a larger historical framework.

\section{MONUMENTS AND MEANING}

Monument as a term in itself is ambiguous; there are no hard and fast rules on what constitutes a monument. The word monument comes to English from the Latin monere, meaning to admonish, instruct, remind; today certain dictionary definitions, Merriam-Webster for instance, provide up to eight variations on the word monument which may place emphasis on a lasting quality, the use as commemorative object, or simple documentation of past places or events. Past materials that belong to, and modern monuments which will become a part of, the archaeological record are typically made of materials like metal and stone, which are meant to withstand time and the elements and take a good deal of effort to remove (Bevan 2007; Bradley 2012; Levinson 1998).

Objects inherently interact with the landscape on which they exist. Monuments, as often larger-than-life stone objects intentionally inserted into a landscape through human action, go one step further and create space. A monument creates a symbolic relationship with its surroundings and forces viewers, consciously or not, to form an association between the space and the object, and to assign meaning to the otherwise arbitrary structure (Auster 1997). Furthermore, monuments are commonly erected in spaces prominent to the public eye. A monument's viewers are then compelled to associate the monument with the community in which they live and operate, thereby associating the monument with a message that the community wants to assert and perpetuate (Osborne 2001; Runia 2007). Kelly (2013) states that monuments are examples of costly signaling_objects which require a great deal of effort to 
construct, but yield few tangible benefits, their true benefits being that they assert a certain message over those who encounter it. In this way, monuments act as what Osborne (2001:50) calls "allegorical statements for the national narrative."

Power dynamics are also inherently at play when monuments are constructed and displayed. Whether a system of power-government, typically_itself erects a monument in a public space, or allows a smaller organization to erect a monument, the dominant powers in a given society are monitoring and either actively or passively supporting the construction of that symbol in the public eye. Furthermore, there is always intent behind monument construction, and therefore through the approval and execution of a proposed monument, the power structures in question are complicit in whatever intention drove the monument's construction. Therefore, by setting a symbol in stone these power structures are not only supporting the monument's construction, but giving legitimacy to the intention behind it (Levinson 1998; Osborne 2001).

Governments or dominant subgroups within a society often use monuments as a tool to transform public space in an attempt to unify the society as a whole, or bring many individuals together based on a common feeling or cause. We see this attempt at unification manifest most often in one of two ways: in the act of commemoration, and in the rebuilding of war-torn areas (Bevan 2007; Levinson 1998; Osborne 2001).

Because monuments are constructed with lasting materials, in the public eye, and serve to transform the meaning of a space, they are a medium particularly suited to commemorate important figures in a society's history. One might easily list a handful of highly visited monuments in the United States erected for a prominent historical figure: the Washington Memorial for George Washington, the Lincoln Memorial for Abraham Lincoln, Mount 
Rushmore for both of the former as well as Thomas Jefferson and Theodore Roosevelt. The Statue of Liberty serves as the very personification of the American melting-pot ideal, with her inscription proclaiming Give me your tired, your poor, your huddled masses yearning to breathe free... In his discussion of monuments as allegories, Auster (1997:221) asserts that "the imperfect human being is gradually forgotten but his name - it does tend to be his, rather than hers - is preserved to personify general qualities of aspiration and achievement." Indeed, with their transformation to monument, we choose to remember each of the aforementioned men for their admirable leadership and forget their flaws. In a similar way, we hold up the ideals embodied in the Statue of Liberty while the President of the United States calls for border walls and the turning away of refugees. Once again, we see that monuments are constructed national narratives, and continually assert a curated heritage that doesn't necessarily reflect the realities of the day. In other words, monuments are certainly relics of the time period in which they were erected, but because they are meant to evoke a specific feeling or viewpoint, they serve an adjacent purpose to written records; monuments are pillars of the past, but they are not and should not be used in place of written, contextualized history.

In the necessary act of rebuilding in the aftermath, countries which have fallen victim to occupation or destruction by an outside force often make monuments out of structures which, pre-war, served the country's citizens in a mundane, daily life type of way. A country may choose to rebuild its landscape as a picture reprint of its pre-war state, thereby reasserting a prewar identity, or rather, to construct a new landscape which demonstrates the population's resilience to the violence it suffered, but which acknowledges the changes it was forced to undertake to emerge on the other side (Bevan 2007). There is a danger in committing too strongly to either of these pursuits, however. In attempting to return to an entirely pre-war state, 
a country may be accused of rewriting history, or attempting to forget a piece of history altogether. On the other hand, in a complete refashioning of architecture and thereby national identity, a country disregards many of its pre-war cultural touchstones. Though it is important to consider that the decision to build again or build anew typically only pertains to the structures of those oppressed in a conflict. Countries tend to demolish or else repurpose sites of their former oppressors as a part of the rebuilding process. For instance, in post-WWII Munich, Nazi outposts were often completely levelled or in some cases turned into rather pragmatic locales such as parking structures or business spaces (Bevan 2007). Likewise, examples of destruction to Stalin monuments abound across former Eastern Bloc countries in the months and years following the end of his dictatorship; one infamous incident occurred in Prague in 1962, when a memorial statue of Stalin which had stood for only seven years was "blown to smithereens" (Levinson 1998:13).

Being that monuments are large, public structures that keep their form even as society changes around them, there is a real and present danger that any given monument will outlast its relevance or even appropriateness in a given context. The Stalin statue destroyed in Prague in 1962 is a case in point. Osborne (2001:56) states that monuments are "sites of contestation between the laws of physics, social change, and human psychology. Simply put, they last too long!" In discussing Nietzsche's view that monumental structures demonstrate "a belief in the coherence and continuity of what is great in all ages," Levinson (1998:7) states that “history...moves relentlessly to mock any such beliefs." As I’ve argued above, monuments are erected with the intention to transform a space by constructing a specific narrative of the past, often through the use of a figure meant to inspire pride or awe, and that narrative is then meant to be perpetuated within the community without foreseeable end. Society, however, is in a constant 
state of flux and therefore the public symbols meant to unify a society's constituents should also change. This is not to say that monuments should be consistently destroyed or replaced; as previously mentioned, monuments of the past are impressive markers of time and examples of the popular mindset of specific populations. Therefore monuments can be valuable pieces of information which enable future generations to understand past cultures. However, because monuments are created for such specific purposes and we associate them most often with greatness, the conditions dictating the systemic context of potentially outdated monuments "may need to be re-evaluated" (Osborne 2001:60).

\section{DESTRUCTION IN THE ARCHAEOLOGICAL RECORD}

The word destruction has many meanings, and intentional destruction perhaps even more. The archaeological record is, in effect, a record of destroyed artifacts; potential artifacts are destroyed at the hands of taphonomic processes, and the differential preservation of cultural materials across time and space is one reason that the archaeological record is incomplete. So when attempting to assess the markers of intentional destruction on archaeological materials, it is necessary to first have a familiarity with archaeological site formation processes and all the forces that can "destroy" the record. Cultural artifacts - man-made objects - exist in one of two contexts, a systemic context where the object interacts with humans within a cultural system, and an archaeological context, where an object is no longer interacting within a cultural system and instead only within the environment of its deposition (Schiffer 1987). The processes by which artifacts move from systemic to archaeological context, then, are site formation processes, and these processes can be either cultural or noncultural. 
A wide range of human actions deposit artifacts into the archaeological record. These cultural formation processes also affect the form in which an artifact enters the record - a record which is further modified by the consideration that artifacts may oscillate between a systemic and an archaeological context multiple times before final deposition. Reuse and refuse are interwoven forms of cultural processes which affect artifacts; reuse of objects can alter patterns of wear as well as alter the form of an artifact altogether, whereas objects may enter the archaeological record simply as refuse at the end of their use-life. Debitage, the waste produced through the reductive process of tool manufacture, is one major category of refuse in the archaeological record (Kunen et al. 2002; Moholy-Nagy 1997). Objects discarded as refuse may also be retrieved later for reuse; large, sturdy materials are often reused after initial discard as fill in construction projects (Moholy-Nagy 1997; Schiffer 1987).

Cultural materials may also be lost, thereby entering the archaeological record. Object size contributes to loss rates, as peoples are more likely to lose track of smaller items. Search efforts for lost items then correspond to the cost of replacement of the item in question. Conversely, it is much less likely for a community to lose a large-scale artifact such as a monument; such large and energetically costly materials are more likely to enter the archaeological record by either ritual caching or abandonment processes. Schiffer (1987:79) explains that ritual caches "must be a reasonably discrete concentration of artifacts [and generally] complete, sometimes unused or easily restored." Kunen et al. (2002) offers an interpretation of ritual caches which recognizes them as groupings of objects interred as an ongoing process aiding in the formation of a people's relationship with their environment. Ritual caches are often relatively safe from scavenging, as the fear of social consequences ward off would-be looters, however with the passage of time, the promise of high material rewards may 
make ritual caches more appealing and prone to damage by scavenging. Cultural abandonment of a settlement also often leads to complete structures and artifacts entering the archaeological record (Cameron 1996), whereas abandonment due to environmental processes (mudslides, volcanic activity, etc.) can either preserve artifacts or destroy them-Pompeii is the classic example of an entire settlement entering the archaeological record in pristine condition due to a volcanic eruption (Schiffer 1987).

Once an artifact or feature — clusters of artifacts which lose integrity when moved-has fallen prey to any of these archaeological formation processes, they also becomes vulnerable to in-situ deterioration processes. Even large stone artifacts, which are most relevant to this discussion, are susceptible to chemical, physical, and biological agents that may lead to breakage and surface deterioration. Chemical weathering is the most common process which affects stone artifacts, generally in the form of water mixing with gases in the atmosphere and forming acids which alter a rock's chemical composition. Biological agents including colonization of a stone's surface by "bacteria, molds, fungi, algae, lichens, and mosses" may also generate acids which lead to deterioration (Schiffer 1987:157). Examples of physical processes that contribute to the deterioration of stone artifacts are freeze-thaw cycles and thermal shock, which both involve expansion and contraction of materials due to freezing water and sun exposure, respectively. The higher porosity a stone exhibits, the more susceptible it is to these agents of decay. Artifacts exposed to running water or high winds in sandy environments often experience a rounding of edges and impact striations by small, fast-moving objects; salt erosion can have the same effects. And various forms of pedoturbation — mixing of soils and sediments — can complicate the archaeological interpretation of artifacts by displacing them from original context, and thereby changing their chronological assignment and association with other artifacts (Van Nest 2002), 
for instance the work of earthworms or other small soil fauna may alter an artifact's vertical positioning in soil, which can confuse its stratigraphic placement but may also actually contribute to the artifact's preservation.

Modern monuments occupy a curious position with regards to archaeological materials; monuments which remain today in the public eye exist in a systemic context, though they are certainly material remains of a past moment in human life, and therefore of archaeological interest due to the insights on the human condition they may provide. In the following sections I discuss two case studies of monuments which did enter the archaeological record and which were vulnerable to natural formation processes for millennia before discovery by archaeologists. With both of these case studies I aim to show the evidence for intentional human destruction to the respective monuments before their deposition into the archaeological record and when possible discuss the historical circumstances surrounding each destruction event. I then examine a third case study of a monument which stood for over a millennium as a pillar of the past, which (very much like modern American monuments) was never deposited into a purely archaeological context, but was nevertheless vulnerable to environmental processes, before its intentional destruction by a modern political regime.

\section{CASE STUDY 1: OLMEC MONUMENTS}

"Olmec culture" refers to the material remains of the peoples who inhabited Mexico's southern Gulf Coast from roughly 1200 to 550 B.C. (Grove 1976; Coe et al. 1967). According to Schiffer (1987:78), the Olmec were "one of prehistory's most dedicated cachers," and the contents of such caches have been a source of debate amongst the archaeological community since explorer José Melgar y Serrano wrote of the half-interred colossal basalt head he'd seen in 
Veracruz in 1869 (Porter 1989). The Olmec did not leave behind a written record, though they did leave caches of statues and monuments buried in clusters, or in at least one instance "laid out in long lines" (Grove 1981:55). In 1940 archaeologist Matthew Stirling began excavations at the Olmec site of La Venta, where he remarked that "almost all of the great stone altars and monuments had been broken and mutilated at the cost of considerable effort" (Sterling 1940:334). Later excavations at the sites of San Lorenzo and Chalcatzingo yielded even greater quantities of carvings in various forms, which were also often "battered and defaced" (Grove 1981:49; Coe et al. 1967).

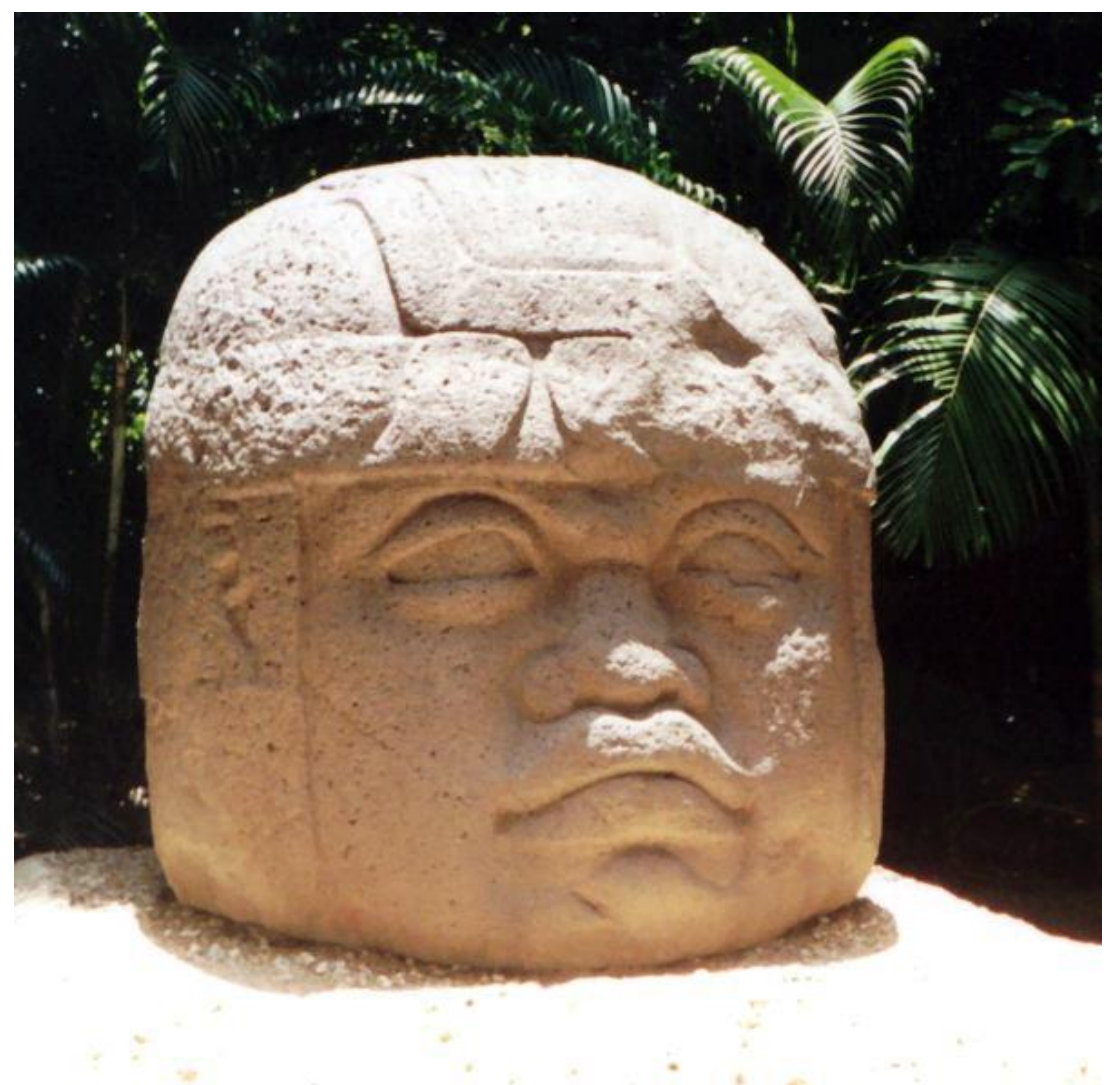

Figure 1. La Venta Monument 1 (Hajer 2001). 
The site of La Venta was occupied by pre-Olmec cultures as early as 1500 B.C. and then by Olmec cultures from 1150 to 500 B.C. (Rust and Sharer 1988). In other words, La Venta was a continuous occupation site for the duration of the Olmec period. According to Grove's (1981) compilation of the data from previous excavations at La Venta, the site has yielded four colossal heads (see Figure 1), seven altars (see Figure 2), twenty anthropomorphic statues, and seventeen reliefs. The damage to the La Venta monuments is as follows: five of the altars were broken, twelve of the anthropomorphic statues were decapitated and two more were otherwise broken, and ten of the reliefs were broken or otherwise effaced. All four colossal heads were completely intact. Dates of monuments are not included in this data set, which is a limitation that follows for the data compiled from San Lorenzo and Chalcatzingo as well.

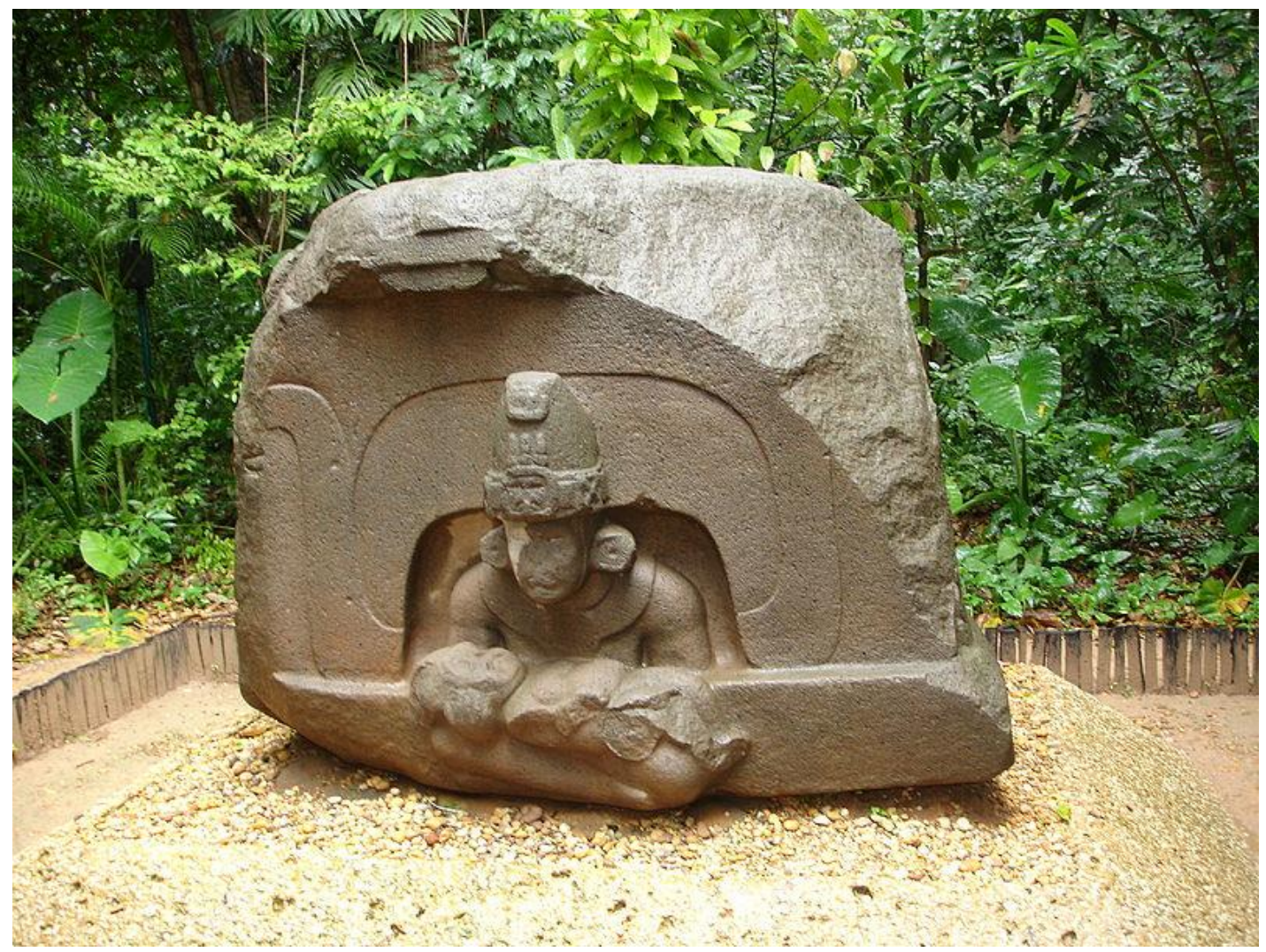

Figure 2. La Venta Altar 5 (Charles 2007). 
San Lorenzo was a site of Olmec occupation from 1200 to 900 B.C. (Coe et al. 1997; Cyphers 1996). The site assemblage contains both more colossal basalt heads and more altars than La Venta — nine and eight, respectively_-despite being active for a shorter interval of the Olmec period. The monumental structures of San Lorenzo also include twelve anthropomorphic statues and six reliefs (Grove 1981). The damage to the San Lorenzo monuments is as follows: all eight of the altars were recovered broken with one (Monument 20) exhibiting additional effacement, eight of the anthropomorphic statues were decapitated and two more were otherwise broken, and four of the reliefs were broken or otherwise effaced. All nine colossal basalt heads were recovered whole.

Chalcatzingo, like La Venta, was occupied by pre-Olmec cultures as early as 1600 B.C., and was a site of continuous Olmec occupation from 1150 to 550 B.C. Chalcatzingo is also somewhat of an outlier, being the only Olmec archaeological site as far inland as the central plateau of Mexico. Grove's (1981; Grove et al. 1976) own excavations yielded neither colossal basalt heads nor altars, but the assemblage contained fifteen reliefs and twelve structures which Grove simply dubs 'monuments.' Of these, two of the reliefs are broken and nine of the monuments are either decapitated, broken, or otherwise effaced. There can be no doubt that many of the Chalcatzingo artifacts were vulnerable to erosion and other natural processes after their deposition into the archaeological record, and it is also likely that this site fell victim to looting between the time of its original abandonment and rediscovery; in some cases, large sections of reliefs_-broken in no discernible pattern — went unrecovered during excavations. However, statues and stelae were often missing one specific piece - the head. Such a pattern is unlikely to emerge due to general loss, abandonment, or natural causes, which has led scholars to hypothesize that not only were these categories of monuments intentionally targeted for 
destruction, but that there was a specific reason the heads were taken elsewhere. Only in one instance has an Olmec decapitated monument head been discovered in archaeological context, in Burial 3 at Chalcatzingo (Grove 1981, 58).

Thus far, I have discussed four types of monuments associated with the assemblages of La Venta, San Lorenzo, and Chalcatzingo- three sites taken here as a representative sample of Olmec occupations across time and space — those being basalt heads, monolithic altars, anthropomorphic statues, and reliefs. Perhaps the most famous category of Olmec monumental architecture, the colossal heads of carved basalt recovered from La Venta and San Lorenzo, exhibit the least signs of destruction of all statues among these assemblages (Grove 1981; Porter 1989); many of them were recovered from buried caches and all were entirely intact save for evidence of erosion. All four of the colossal heads from La Venta and eight of nine from San Lorenzo have pits, grooves, and/or niches etched into the headdress, though this form of destruction never mars the monuments' facial features.

The monolithic table-top altars also common to Olmec archaeological sites and which are even larger than the basalt heads are the most damaged among recovered Olmec monuments (Grove 1981). Given their size and the sheer extent of the damage to these altars, Grove (1981:49) supports Stirling's earlier assumption by postulating that their destruction “obviously required forethought and considerable effort," as opposed to breakage by natural processes. In addition to the frequently destroyed altars, "anthropomorphic statues [were] almost always found decapitated," and stelae — upright stone slabs depicting reliefs — were either broken or showed defacement such as pitting or grooving to the extent of complete obliteration of the original image (Grove 1981:50). 
The question then becomes, why are colossal basalt heads the only monuments that are entirely spared from destruction? Destruction by warring groups, as was a popular hypothesis of early anthropologists working with Olmec civilization, does not explain why one category of monument is so consistently spared while the others are not, and it assumes that warring parties dedicated considerable time to the destruction of their opponents monuments. That evidence of this pattern of destruction persisting throughout Olmec culture, from 1200 to 550 B.C., would then suggest that warfare was also a consistent occurrence. For this same reason, civilian uprisings against the chiefs represented in Olmec monumental art is too narrow an explanation.

Without a historical record, archaeologists must follow alternate and less-direct lines of evidence in the attempt to explain Olmec monument destruction. The one head found in a burial context at Chalcatzingo may support the hypothesis that the decapitation of statues served a ritual, and perhaps even mortuary, purpose. Furthermore, using ethnographic evidence from modern South American tropical forest cultures, Grove (1981) hypothesizes that the Olmec believed their chiefs, represented by the monolithic table-top altars and bas-relief carved stelae which are so frequently mutilated in the archaeological record, possessed supernatural powers. When the chief died, their power went uncontrolled, which was very dangerous and therefore the monuments which also represented that power had to be destroyed. This explanation still creates an enigma of the unmutilated colossal basalt heads, though many of these were found in caches with what Grove (1981:65) interprets as "ceremonial markings," and were still apart of the burial activity which included the destruction of the other likenesses. Porter (1989) goes on to develop an explanation of a curious feature of some colossal basalt heads - flat backs with residual carvings unrelated to the final "head" state of the monuments - wherein the heads were actually 
recarvings of table-top altars. In this hypothesis, by recarving the altars which represented the chiefs' supernatural power, the power would have been neutralized.

Scholars claim very few certainties concerning the study of Olmec monuments; destruction to these monuments at times can be well explained by natural processes or common cultural processes such as looting. In many cases, however, the destruction or even the absence of destruction begs further explanation. The patterns which emerge when monument typology is considered suggests that both religious and political concerns were at play when a monument was destroyed and entered into the archaeological record. Then, evidence from three sites spanning approximately 600 years strongly suggest that these destruction events were culturally prescribed and recurrent.

\section{CASE STUDY 2: THE MORTUARY TEMPLE OF HATSHEPSUT}

In the field season of 1922-1923, under the commission of the Metropolitan Museum of Art of New York, archaeologist Herbert Winlock oversaw the excavation of a debris pit on the south side of the avenue of Deir el-Bahri, the site of an ancient Egyptian mortuary temple complex in the Theban Necropolis. Winlock's goal was to continue to recover XI Dynasty antiquities like he had done in the previous season. What he and the excavators found in the debris pit, however, were the remains of the granite, sandstone, and limestone statues from the mortuary temple of Hatshepsut (Figure 3), the fifth pharaoh of the XVIII Dynasty (reigning c. 1479-1458 B.C.), which had been conspicuously missing for more than 3000 years (Winlock 1923). After the 1922 discovery of this pit, quickly dubbed the 'Hatshepsut hole,' Winlock continued to work with the antiquities of Hatshepsut through 1936, and in the field seasons of 
1926-1928 Winlock's team began excavations of a quarry on the north side of the site's avenue, which yielded even more of the missing statues of Hatshepsut (Winlock 1928; Arnold 2005a).

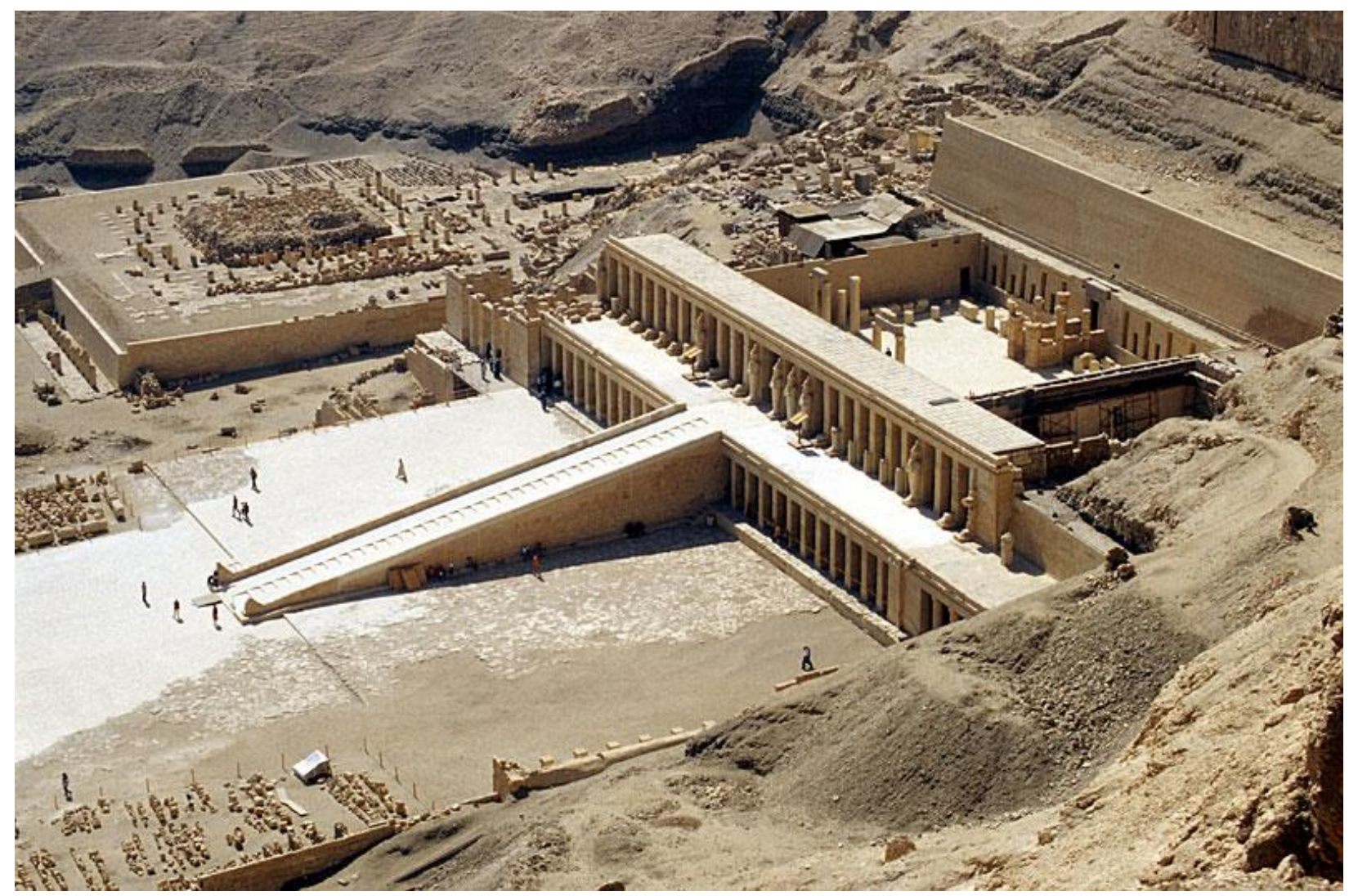

Figure 3. Arial view of the Mortuary Temple of Hatshepsut at Deir el-Bahri (Unger 2002).

Based on information available from ancient Greek and Egyptian texts, modern scholars were previously aware that after her death, Hatshepsut's successor led a campaign to strike her image as king from the historical record of Egypt (Arnold 2005b; Cooney 2014; Dorman 2005; Waddell 1940). Therefore, even before the archaeological discovery of these artifacts, "the tourist and the student [were] both familiar with the way [Thutmose III's] masons hacked every mention of Hatshepsut off the walls of Deir el-Bahri" (Winlock 1923:32). It was not until the 1922-1923 excavation, however, that the archaeological record could speak to these past events. It is necessary, then, to recognize the potential bias in the original site reports of the excavations; 
Winlock's words show that the aforementioned historical texts may have given the excavators presuppositions as to how the monuments in question entered the archaeological record.

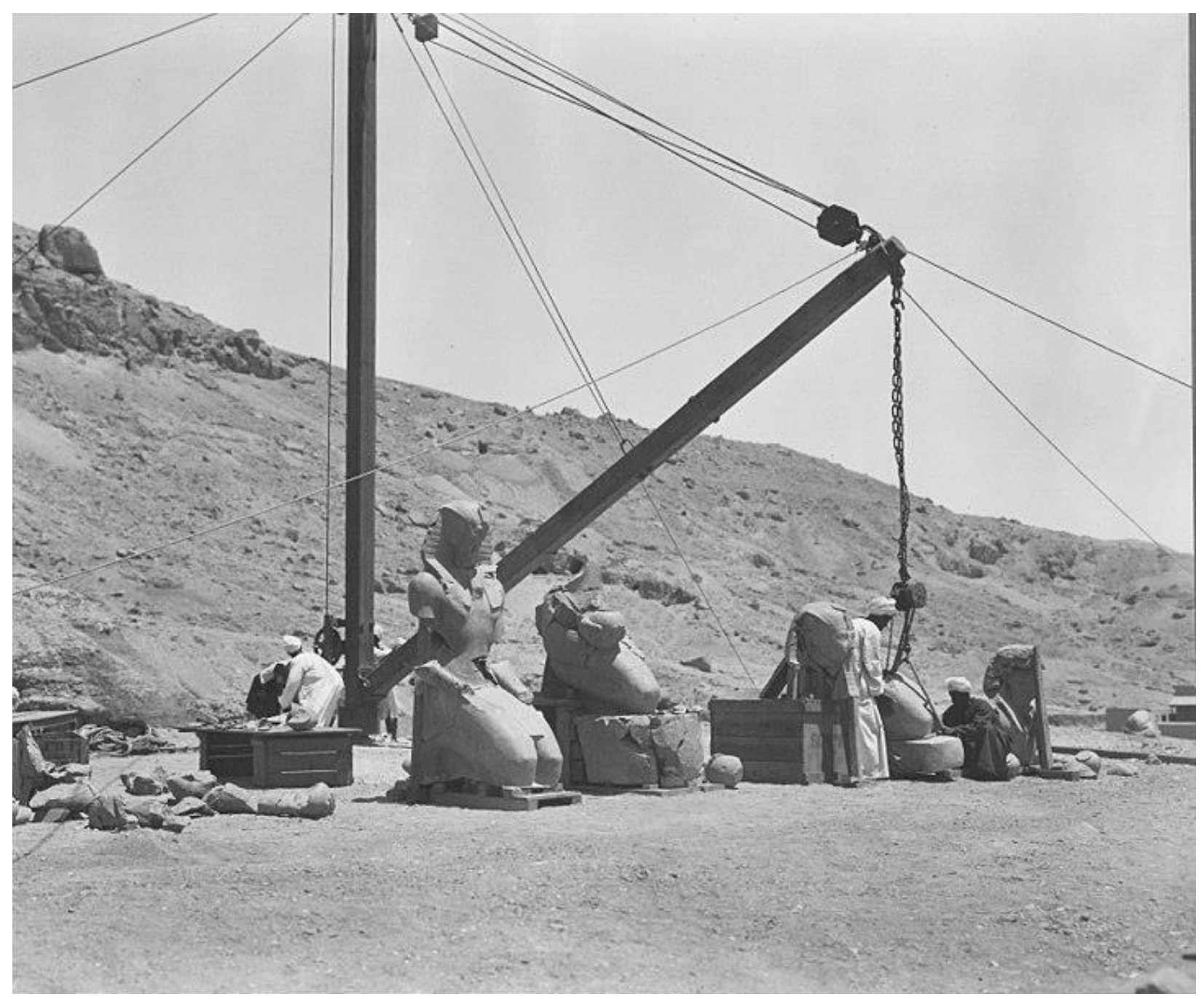

Figure 4. Granite statues of Hatshepsut being reassembled during the excavations of 1927-28 (Rogers Fund 1929).

In the field season of 1923-1924, excavators discovered the remnants of at least ten red granite figures of Hatshepsut in the 'Hatshepsut Hole,' all broken at the neck, waist and base, and all of the bases were missing from the assemblage. The paint on the statues was also well preserved (Winlock 1923). Then, in the field season of 1927-1928, more than fifty granite and sandstone statues statues of Hatshepsut were were discovered in an area - 'the quarry'- 
alongside the road leading to her temple (Figure 4), and while the damage to these statues varies greatly, especially depending on their size, many were decapitated (the larger ones almost always). Some of the statues, particularly those of smaller stature, were hardly broken up at all and some were even buried whole. Though the uraeus, the serpent symbol affixed to the front of a pharaoh's headdress, was missing from every statue recovered; Winlock writes, "always the uraeus - the symbol of the kingship — was battered away" (Winlock 1928:15). Furthermore, excavators found an abundance of red granite chips around the top of each pit and large chunks of the statues at the bottom of the pits themselves. Among the small debris from the surrounding area of the pits, the excavators were able to salvage in some cases the nose and the uraeus of statues.

The state of the artifacts found in both locations contain patterns which suggests their quick and methodical destruction. The fact that much of the statues' original paint was intact upon discovery points to a relatively short interval between their creation and their deposition (Winlock 1923; 1928). Furthermore, the granite chips around the tops of the pits suggests that the statues were deconstructed just before being pushed in (Winlock 1928; Dorman 2005). Winlock (1923) posits that the bases of the statues, being of regular, block-like shape, were most likely taken to the city and repurposed.

Many of the statues excavated from the Hatshepsut hole and 'the quarry' outside Hatshepsut's mortuary monument at Deir el-Bahri weighed several tons, and therefore it is unlikely that they were deposited in either site without specific human intention; that is, these statues were not victims of loss nor of cultural abandonment, which is also evidenced by the continuing nature of Egyptian settlements and civilization in the area for centuries after Hatshepsut's death. Then, where it is possible and perhaps even probable that some materials 
from Hatshepsut's temple were removed and repurposed, such as the bases of statues, the dozens of remaining statues excavated almost in their entirety between the 1922 and 1928 field seasons strongly suggest that Hatshepsut's temple was not looted for use of its material wealth. And though the statues of Hatshepsut comprise the whole of the assemblage of both pits in question, the consistent, specific destruction to these statues-chipping of the face and removal of the uraeus and head—suggests that ritual caching was not their driving depositional cause. We can see the lack of commemorative or ritualistic intention particularly where Tuthmosis III occasionally left Hatshepsut's monuments standing, but he had her name stuck from their bases and replaced with the name of one of her predecessors (Cooney 2014; Arnold 2005b; Dorman 2005; Roth 2005). Finally, no historically documented nor archaeologically evident natural disasters occured near Deir el-Bahri around the time of Hatshepsut's death, and therefore, we may also rule out most environmental causes of deposition. The statues did suffer from in-situ deterioration processes; for instance, parts of the quarry were waterlogged upon excavation and the limestone materials therein were badly deteriorated (Winlock 1928). However, Winlock (1928:15) also makes the claim that "in one respect the mutilation and the burial of these statues have actually worked for their preservation," in that the statues of Hatshepsut at Deir el-Bahri were not exposed to weathering from the harsh desert environment for long before their burial essentially ensured their protection from processes such as sandblasting, therefore the granite and sandstone materials remained well preserved.

In sum, Hatshepsut ruled as the female king of Egypt for twenty years, and "constructed temples and obelisks according to accepted traditions and left behind more stone temples and monuments than any previous Egyptian king" (Cooney 2014:230). According to written texts, after her death her image as king was systematically removed from the Egyptian landscape, 
while her images as queen were left untouched. Winlock's discovery of the Hatshepsut hole in 1922 allowed for the archaeological record to speak to one historically documented instance of monument destruction, and the archaeological evidence strongly supports the written record in that it suggests swift and intentional removal of the statues of Hatshepsut from her temple at Deir el-Bahri (where her image as king would have been particularly emphasized) and their deposition into the archaeological record. There are many interesting details in the story, constructed by historians and archaeologists alike, of the destruction throughout Egypt of Hatshepsut's image as king after her death; for the most part, these details are beyond the scope of this work. However, since the discovery of the debris pit and the quarry at Deir el-Bahri, the most widely accepted dates for the destruction in question are twenty years after Hatshepsut's death, which do not support a revenge plot by Hatshepsut's successor, Thutmose III. Dorman (2005:269) summarizes an alternative theory that "the timing and short duration of the attack on Hatshepsut's image and name suggest that it was driven by concerns related to the royal succession and ceased once [Thutmose III's son] was securely enthroned." Cooney (2014), among others, echoes this position and both the historical and the archaeological evidence (Winlock 1923, 1928; Waddell 1940; Cooney 2014; Arnold 2005b; Dorman 2005; Roth 2005) suggest at least a political motivation, particularly concerning regime change, behind the destruction of the monuments of Hatshepsut.

\section{CASE STUDY 3: THE GRAND BUDDHAS OF BAMIYAN}

The Grand Buddhas of Bamiyan, carved into a cliff face along the Silk Road trade route in central Afghanistan, were once the two largest standing buddha statues in the world (UNESCO; Colwell-Chanthaphonh 2002). Constructed prior to the spread of Islam in the region circa 800 A.D. and perhaps as early as 600 A.D., these statues stood 55m (170 feet) and 38m 
(115 feet), respectively (Higuchi and Barnes 1995, 291; Crosette 2001; Behzad and Qarizadah 2015). Following Buddhist tradition, the cave temples at Bamiyan were geographically remote to allow monks to practice their religion in solitude; however, the Grand Buddhas therein were anything but typical of Buddhist monuments of the time. According to Higuchi and Barnes (1995:293), the Greek and Roman "western tradition of monumental sculpture seems to have melded with the Buddhist worship of statues at Bamiyan to produce the first grand buddha statues in Buddhist cave art." In addition to the great effort the construction of the buddhas would have required, the niches in which each statue stood were uniquely and extravagantly painted, and evidence of wooden balconies which once hung near the buddhas' heads signal that these statues, in their extravagance, were meant to be worshipped by crowds larger than those comprised of monks alone and perhaps even by royalty.

For the 1200-1400 years that the they stood, the Grand Buddhas of Bamiyan as well as the murals within their niches were vulnerable to destruction by "natural exfoliation" (Higuchi and Barnes 1995:299) ie. sand erosion, on a daily basis. However, beginning with the introduction of Islamic cultures to central Afghanistan around 800 B.C., Buddhist cave temples became obsolete as places of worship, and the Grand Buddhas of Bamiyan fell victim to historically documented, intentional destruction on several occasions. For instance, in a great majority of the murals in the buddhas' cave niches, the faces of Buddhist images were defaced. Genghis Khan entered the valley in the 13th century and damaged the statues; some murals were destroyed in their entirety and assaults were also made to the caves; in 1647, the Mongol leader Aurangzeb shot a cannon at the West Grand Buddha, which damaged the lower legs of the statue; and in the twentieth century, "the faces of the two Grand Buddhas have been shorn away 
and both sets of hands broken off," and the caves also used as barracks during the Afghan civil war of the 1980s and 1990s (Higuchi and Barnes 1995:300; Colwell-Chanthaphonh 2002).

In early 2001, the Grand Buddhas stood as evidence of these past instances of destruction, as well as reminders of the prominence of Buddhism in Bamiyan in the sixth and seventh centuries; they were faceless, without hands, and in the case of the West Grand Buddha, standing on legs obliterated by a seventeenth century cannon shot. In The plundered past (1973:207), American journalist Karl Meyer wrote that the statues "could be rubble by the end of the century," and nearly thirty years later, his forecast proved true. The buddhas had been under threat of destruction by the Taliban regime, specifically, as early as 1998. Then in February 2001 the Taliban's supreme leader, Mulla Mohammed Omar, proclaimed that "in...the verdict of the Afghan Supreme Court it has been decided to break down all statues/idols present in different parts of the country. This is because these idols have been gods of the infidels..." (ColwellChanthaphonh 2002:76; Crosette 2001). Despite the "international outcry" that followed, the Taliban detonated explosives in the Grand Buddhas over a twenty-five day period in March 2001 (Colwell-Chanthaphonh 2002:76; Crosette 2001; Holtorf 2006). One prisoner ordered to participate in the bombings later told BBC (Behzad and Qarizadah 2015) that he and others were forced to "drill holes into the statue to plant the dynamite." When they were through, the Grand Buddhas of Bamiyan were reduced to heaps of rubble in their cave niches (Figure 5).

This instance of monument destruction differs from those previously discussed at Olmec sites on Mexico's southern gulf coast and at the site of Deir el-Bahri in Egypt on several counts. First, the Grand Buddhas of Bamiyan represent archaeological materials that were never truly 'deposited' into the archaeological record, though the nature of the context in which they existed certainly shifted through time; the Grand Buddhas were constructed when Buddhism was the 


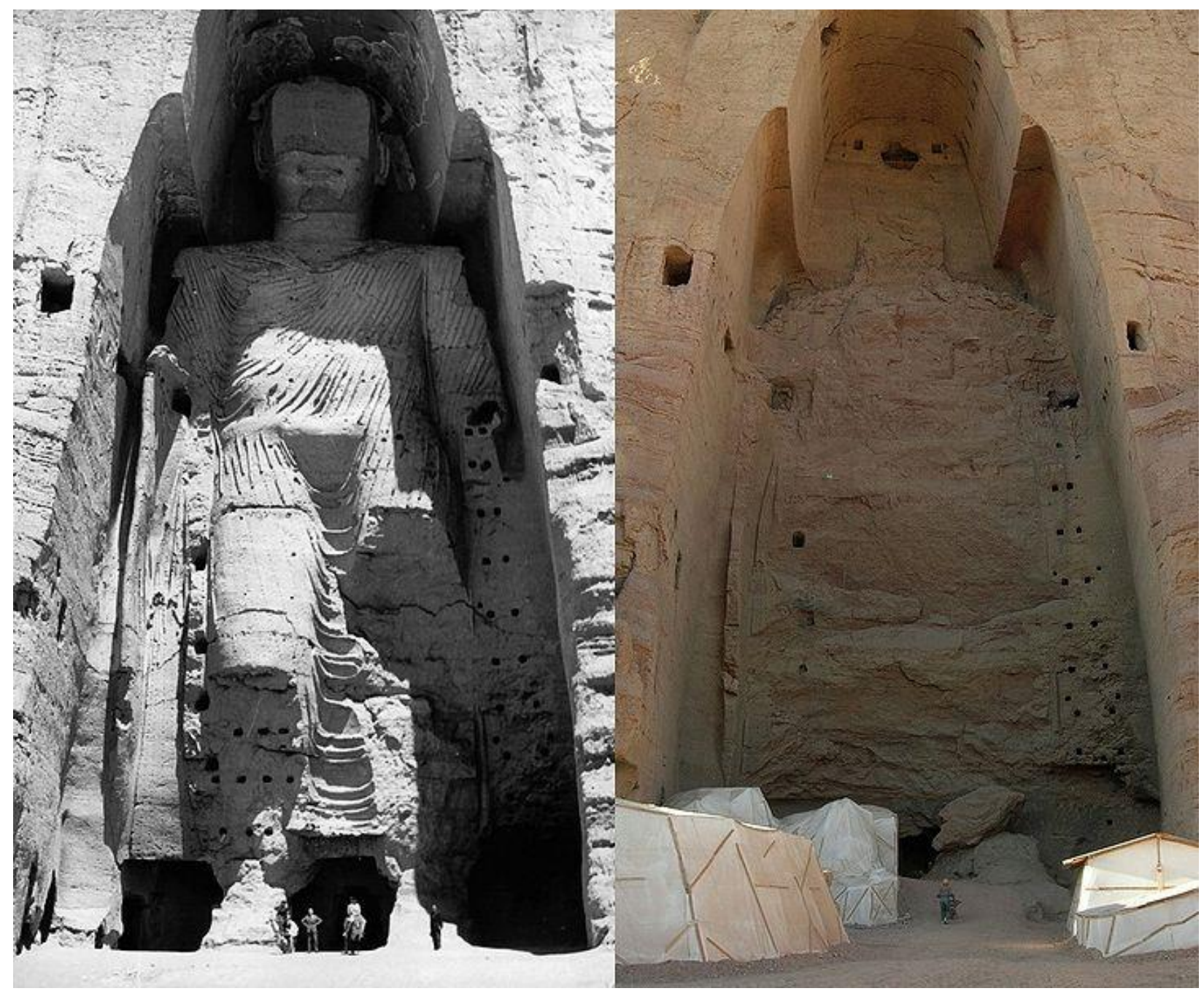

Figure 5. To the left: the West Grand Buddha before the 2001 bombings; to the right: the West Grand Buddha after the 2001 bombings (Zaccarias 2009).

dominant system of belief in Afghanistan and in their original systemic context existed as religious idols in cave temples meant for the practice of such religion. The monuments stood for 1200-1400 years - albeit surviving this interval despite extensive damage and not in lieu of itin which time Islam largely replaced Buddhism in the region, and the Grand Buddhas remained in a systemic context but were used at various times as targets, camps for military groups, and as reminders of the past - in the view of the Taliban, dangerous reminders. The forces whom brought a final end to the Grand Buddhas had little connection to those who constructed them, 
and were a part of an entirely different time, religion, political regime, and different technological age. This becomes evident in Mulla Mohammad Omar's February 2001 order of destruction in which he said, "The real God is only Allah and all other false gods should be removed...If people say these are not our beliefs but only part of the history of Afghanistan, then all we are breaking are stones" (Colwell-Chanthaphonh 2002:76). Finally, the written records and photographic documentation of the destruction of the Grand Buddhas of Bamiyan set this instance of monument destruction apart from the mutilated altars of the Olmec archaeological record where we do not have a written record in any form, and the defacement of the mortuary temple of Hatshepsut, where scholars must negotiate the written record and the informational gaps therein with 3000 years of distance. Here, we have statements-really, demonstrations of power-from the perpetrators of the destruction claiming that the Grand Buddhas were idolatrous representations of a false god and for that reason, they had to be destroyed.

\section{DISCUSSION}

Monuments fulfill a very specific role in the public eye as symbols which transform space, most often through commemoration of a person or event, and are intended to inspire awe and represent the dominant ideologies of a society. Colossal basalt heads and monolithic tabletop altars are two examples of monuments common to the assemblage of Olmec archaeological sites, where the former were likely carved in honor of Olmec chiefs and the latter served ritual purposes wherein the chiefs - also depicted on the reliefs carved into the altars - were thought to wield supernatural powers. Monuments representing Hatshepsut as the king of Egypt served political as well as religious ceremonial purposes and Hatshepsut, in erecting them, was following a tradition prescribed by the entire lineage of Egyptian rulers who had come before her. The Grand Buddhas of Bamiyan were constructed when buddhism was the dominant system 
of belief in Central Afghanistan and were very likely meant to be viewed by monks and the elite alike, as idols to the practice of their religion.

Confederate monuments honor men who are most remembered for participating in a failed rebellion against the United States of America and defending the belief that the "cornerstone [of the Confederacy] rests upon the great truth, that the negro is not equal to the white man; that slavery — subordination to the superior race-is his natural and normal condition" (from the Cornerstone Speech given by Confederate Vice President Alexander H. Stephens, 1861). Confederate General Robert E. Lee also recognized the emotional, rather than historical, implications of monument construction, responding to an invitation to speak at the dedication to a Gettysburg monument: "I think it wiser not to keep open the sores of war but to follow the examples of those nations who endeavored to obliterate the marks of civil strife, to commit to oblivion the feelings engendered" (1869).

While some Confederate monuments were erected as memorials to fallen soldiers in the years immediately following the Civil War, the majority of Confederate monuments which still stand in the U.S. today are artifacts from one of two surges in Confederate monument construction, between 1900-1910 (for example, the statue of General Robert E. Lee in the National Statuary Hall at the U.S. Capitol, Figure 6) and 1950-1970. These two intervals in U.S. history correspond with the initial enactment of Jim Crow Laws and a resurgence of Klu Klux Klan membership in the South, and the Civil Rights Movement, respectively, and reveal specific intention behind Confederate monument construction during these periods (The Southern Poverty Law Center 2016); during a time when counter-cultures were attempting to change societal values, the white dominant powers in the states in question (the majority former Confederate states) used monuments as a tool to assert their narrative of segregation and racism. 


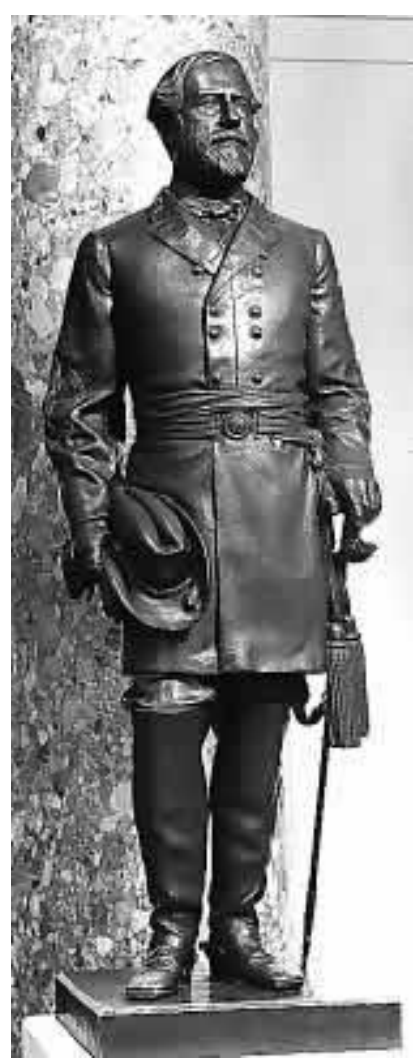

Figure 6. Bronze statue of Confederate General Robert E. Lee, gifted to the National Statuary Hall Collection of the U.S. Capitol by the commonwealth of Virginia in 1909.

The case studies discussed here are but a small selection of examples of defaced and dismembered monuments from the archaeological record; nevertheless, they provide insight into the circumstances surrounding monument destruction from different cultures at different times in human history. Because Olmec monumental architecture was continually defaced (or conspicuously spared from defacement) in a patterned way over approximately 600 years of settlement, scholars believe that the practice must have been culturally prescribed and may have been connected to both the politics of Olmec chiefdoms and to religious beliefs wherein, upon the death of an Olmec chief who's supernatural power was at least partially represented in monumental architecture, monuments were destroyed to tame power left uncontrolled. Therefore, we can surmise that Olmec monuments often served both as honorific and ritual/religious symbols which fulfilled their purpose during the life of a chief and were ritually 
disposed of by the same culture that erected them once their purpose was complete. The mortuary monuments of Hatshepsut at Deir el-Bahri were meant to commemorate Hatshepsut as the fifth pharaoh of the XVIII Dynasty of Egypt. However, her immediate successor stripped her statues of their likeness as king and removed them from her temple so that her lineage would lose a legitimate claim as heir to the pharaonic throne. Hatshepsut's monuments existed in the systemic context for which they were erected for only two short decades before they were removed by the next dominant political agenda. The Grand Buddhas of Bamiyan spent much less of the 1200-1400 years that they stood as actual religious symbols than as targets for attack by other religious and political forces, until they were completely obliterated by a political entity with a religious agenda and also no cultural connection to those who had originally constructed the Buddhas.

With the first case study, we have no written record documenting the destruction events evident in the Olmec archaeological record, and yet there is no 'erasure of history' inherent in the Olmec practice of destroying monuments; this is because the destruction of Olmec monuments was a part of their history. In the latter two case studies the historical record provides knowledge of the past, and the destruction of the monuments in question have not obliterated the figures from historical memory. Indeed, the destruction of Hatshepsut's monuments and the Grand Buddhas of Bamiyan is just as much a part of history as their construction. Holtorf (2006:106) asserts that history "does not benefit from increased preservation, nor can it be harmed by excessive destruction." Going one step further, I would argue that the histories of these monuments have actually been further documented and information on them more widely disseminated after their destruction than would have occurred otherwise; volumes upon volumes have now been written about the intricacies of destruction in 
the archaeological records of both the Olmec and of Hatshepsut, and the monuments in question have reentered systemic context through "museumization" (Levinson 1998:121) where they are surrounded by historical context. Even the Grand Buddhas of Bamiyan, which were too damaged to reconstruct, have at times reentered systemic context in the form of 3D-light projections depicting them in their original state (Davy 2015).

The removal of Confederate monuments would not alter the history of the Civil War nor future generations' understanding of it, and 'museumizing' Confederate monuments would actually contribute to the historical context they provide while simultaneously shifting their systemic context from objects to be revered to objects of the past from which we can learn; though the answer to the question of what is to be done with Confederate monuments across the United States is beyond the scope this paper, and 'museumization' is only one in a list of options. Here, I have attempted to demonstrate that Confederate monuments fit into a pattern of monuments throughout human history which were erected to transform public spaces and assert certain ideals of a dominant subgroup of society, and which have since their construction outlived their original purpose. Given that 'heritage preservation' to the extent that we see now is a relatively recent Western ideal (Holtorf 2006), in addition to the many examples - including the three analyzed here — of monument destruction in the archaeological record, it is neither surprising nor unprecedented that the function of Confederate monuments is now being called into question. Hopefully more scholarly work will follow which supports the above argument that monuments serve a complementary purpose to history and that their being erected or removed certainly does not affect history as modern society maintains or perceives it. Following such work, the United States public may be able to have a constructive conversation concerning the fate of outdated monuments across the country. 


\section{ACKNOWLEDGEMENTS}

I would like to thank Dr. Virginia Butler for unwavering support and a diligent eye through many drafts and revisions. This research was supported by the University Honors College of Portland State University.

\section{REFERENCES CITED}

Arnold, Dorothea

2005a A Chronology: The Later History and Excavations of the Temple of Hatshepsut at Deir el-

Bahri. In Hatshepsut: From Queen to Pharaoh, edited by Catharine H. Roehrig, pp. 290-293.

New York, NY: Metropolitan Museum of Art.

Arnold, Dorothea

2005b The destruction of the statues of Hatshepsut from Deir el-Bahri. In Hatshepsut: From

Queen to Pharaoh, edited by Catharine H. Roehrig, pp. 270-276. New York, NY: Metropolitan

Museum of Art.

Auster, Martin.

1997 Monument in a Landscape: The Question of 'meaning.' Australian Geographer 28(2):219-

27. DOI:10.1080/00049189708703194, accessed October 13, 2017.

Behzad, Nasir, and Daud Qarizadah

2015, March 12 The man who helped blow up the Bamiyan Buddhas. Electronic document, http://www.bbc.com/news/world-asia-31813681, accessed February 21, 2018.

Bevan, Robert

2007 The Destruction of Memory: Architecture at War. Reaktion Books.

Bidgood, Jess.

2017 Confederate Monuments Are Coming Down Across the United States. Here's a List.

Electronic document, https://www.nytimes.com/interactive/2017/08/16/us/confederatemonuments-removed.html, accessed October 13, 2017.

Bradley, Richard

2012 The Significance of Monuments: On the Shaping of Human Experience in Neolithic and Bronze Age Europe. Routledge.

Brundage, W. Fitzhugh, and Pierre McGraw

2017 Why America is wrestling with Confederate monuments. Electronic document, https://www.pbs.org/newshour/show/america-wrestling-confederate-monuments, accessed October 13, 2017.

Cameron, Catherine M. 
1996 Abandonment and archaeological interpretation. In The abandonment of settlements and regions: ethnoarchaeological and archaeological approaches. Edited by Catherine M. Cameron and Steve A. Tomka, pp. 1-6. Cambridge University Press.

Charles, Ruben

2007 File:La Venta Altar 5 (Ruben Charles).jpg. Wikipedia Commons, March 12, 2007.

https://commons.wikimedia.org/wiki/File:La_Venta_Altar_5_(Ruben_Charles).jpg, accessed May 11, 2018.

Colwell-Chanthaphonh, Chip

2003 Dismembering/disremembering the Buddhas: Renderings on the Internet during the Afghan purge of the past. Journal of Social Archaeology, 3(1), 75-98.

DOI:10.1177/1469605303003001100, accessed February 7, 2018.

Cooney, Kara

2014 The Woman Who Would Be King: Hatshepsut's Rise to Power in Ancient Egypt. New York: Broadway Books.

Crosette, Barbara

2001 Taliban Explains Buddha Demolition. Electronic document, http://www.nytimes.com/2001/03/19/world/taliban-explains-buddha-demolition.html, accessed February 21, 2018.

Cyphers, Ann

1996 Reconstructing Olmec life at San Lorenzo. In Olmec art of ancient Mexico, pp. 61-71.

Davy, Steven

2015 They were destroyed by the Taliban. But now the giant Buddha statues of Bamiyan have returned with 3-D light projection. Electronic document, https://www.pri.org/stories/2015-0611/they-were-destroyed-taliban-now-giant-buddha-statues-bamiyan-have-returned-3-d, accessed February 21, 2018.

Dorman, Peter F.

2005 The Proscription of Hatshepsut. In Hatshepsut: From Queen to Pharaoh, edited by Catharine H. Roehrig, pp. 267-269. New York, NY: Metropolitan Museum of Art.

Greaves, Alan M., and Barbara Helwing 2003 Archaeology in Turkey: The Stone, Bronze, and Iron Ages, 2000. American Journal of Archaeology, 107(1), 71-103.

Grove, David C.

1981 Olmec Monuments: Mutilation as a Clue to Meaning. In The Olmec and their neighbors: essays in memory of Matthew W. Stirling, edited by pp. 49-68.

Grove, David C., Kenneth G. Hirth, David E. Bugé, and Ann M. Cyphers 1976 Settlement and Cultural Development at Chalcatzingo. Science, 192(4245):1203-10. 
Hayer

2001 File:Mexico.Tab.OlmecHead.01.jpg. Wikipedia Commons, July 2001.

https://commons.wikimedia.org/wiki/File:Mexico.Tab.OlmecHead.01.jpg, accessed May 11, 2018.

Higuchi, Takayasu, and Gina Barnes

1995 Bamiyan: Buddhist Cave Temples in Afghanistan. World Archaeology, 27(2), 282-302.

Holtorf, Cornelius

2006 Can less be more? Heritage in the age of terrorism. Public Archaeology, 5(2), 101-109.

DOI:10.1179/pua.2006.5.2.101, accessed February 7, 2018.

Kunen, J. L., Galindo, M. J., \& Chase, E.

2001 Pits and Bones: Identifying Maya ritual behavior in the archaeological record. Ancient Mesoamerica, 13(2):197-211.

Levinson, Sanford

1998 Written in Stone: Public Monuments in Changing Societies. Duke University Press.

Meyer, K. E.

1973 The plundered past. New York: Atheneum.

National Parks Service

2016 Archaeology Law and Ethics. Electronic document,

https://www.nps.gov/archeology/public/publicLaw.htm, accessed January 17, 2018.

Osborne, Brian S.

2001 Landscapes, Memory, Monuments, and Commemoration: Putting Identity in Its Place.

Canadian Ethnic Studies; Calgary, 33(3):39-77.

Rogers Fund

1929 Large Kneeling Statue of Hatshepsut. Wikipedia Commons, July 12, 2017.

https://commons.wikimedia.org/wiki/File:Large_Kneeling_Statue_of_Hatshepsut_MET_M9C_3

12-crop.jpg, accessed May 11, 2018.

Roth, Ann M.

2005 Erasing a Reign. In Hatshepsut: From Queen to Pharaoh, edited by Catharine H. Roehrig, pp. 277-283. New York, NY: Metropolitan Museum of Art.

Runia, Eelco

2007 Burying the Dead, Creating the Past. History and Theory 46(3):313-25.

Rust, William F., and Robert J. Sharer

1988 Olmec Settlement Data from La Venta, Tabasco, Mexico. Science, 242(4875):102-4. 
Schiffer, Michael B.

1996 Formation processes of the archaeological record. Salt Lake City: University of Utah Press.

The Southern Poverty Law Center

2016 Whose Heritage? Public Symbols of the Confederacy (Special Report). Electronic document, https://www.splcenter.org/20160421/whose-heritage-public-symbols-confederacy, accessed March 1, 2018.

Suerth, Jessica

2017 Here Are the Confederate Memorials That Will Be Removed after Charlottesville. Electronic document, http://www.cnn.com/2017/08/15/us/confederate-memorial-removal-ustrnd/index.html, accessed October 13, 2017.

\section{UNESCO}

2018 Network of the Silk Road Cities. (n.d.). Electronic document, https://en.unesco.org/silkroad/network-silk-road-cities-map-app/en, accessed April 10, 2018.

Unger, Roland

2002 File:ThebesTempleHatshepsutAerial3.jpg. Wikipedia Commons, February 22, 2002. https://commons.wikimedia.org/wiki/File:ThebesTempleHatshepsutAerial3.jpg, accessed May 11, 2018.

Van Nest, Julieann 2002 The good earthworm: How natural processes preserve upland Archaic archaeological sites of western Illinois, U.S.A. Geoarchaeology, 17(1):53-90.

Waddell, William G.

1940 Manetho. W. Heinemann Limited.

Wilson, Elizabeth

2006 The Queen Who Would Be King. Electronic document, https://www.smithsonianmag.com/history/the-queen-who-would-be-king-130328511/, accessed November 12, 2017.

Winlock, Herbert E.

1923 The Museum's Excavations at Thebes. The Metropolitan Museum of Art Bulletin, 18(12.2), 11-39. DOI: 10.2307/3254661, accessed January 26, 2018.

Winlock, Herbert E.

1928 The Egyptian Expedition 1927-1928: The Museum's Excavations at Thebes. The

Metropolitan Museum of Art Bulletin, 23(12), 3-28. DOI:10.2307/3256031, accessed January 25, 2018.

Zaccarias

2009 File:Taller Buddha of Bamiyan before and after destruction.jpg. Wikipedia Commons, October 24, 2009. 
https://commons.wikimedia.org/wiki/File:Taller_Buddha_of_Bamiyan_before_and_after_destru ction.jpg, accessed May 11, 2018. 